syndrome compared with none in the treated group. ${ }^{19}$ The incidence of proteinuria and the number of readmissions for hypertension were also reduced.

$\beta$ Blocking drugs cross the placenta and are excreted in small amounts in breast milk. ${ }^{20-23}$ Babies born to hypertensive women taking acebutolol have blood pressures up to $13 \mathrm{~mm}$ $\mathrm{Hg}$ lower than those from mothers whose hypertension was not treated with acebutolol. ${ }^{22}$ Follow up studies, however, do not suggest that this transfer is of any importance, at least in patients taking atenolol. ${ }^{24}$ Although the fetal heart rate may be slower in mothers taking $\beta$ blockers, reactivity is usually preserved and obstetricians may still use cardiotocography for the assessment of fetal distress before and during labour. ${ }^{25} 26$

It has been claimed that oxprenolol is superior to methyldopa in the treatment of hypertension in pregnancy because it has been associated with an increase in birth weight ${ }^{17}$; nevertheless, this claim was not substantiated in a subsequent, larger study. ${ }^{26}$ It has also been suggested that labetalol has specific advantages because of its actions in counteracting platelet aggregation ${ }^{27}$ and reducing placental vascular resistance, ${ }^{28}$ but the clinical value of these effects has to be confirmed by clinical trial.

In one study babies born to women taking labetalol were up to $500 \mathrm{~g}$ heavier than those from women taking atenolol. ${ }^{20}$ This may be an effect of additional $\alpha$ blocking activity. The study was small (total 56 patients), however, and not randomised; furthermore, the patients treated with atenolol were managed between 1980 and 1981 , and the patients treated with labetalol after 1981 .

Given the relative safety of $\beta$ blocking drugs in pregnancy, ${ }^{29}$ and the advantages of $\beta$ blockade compared with placebo, ${ }^{19}$ should treatment with $\beta$ blocking drugs replace methyldopa as the drug of first choice for hypertension in pregnancy? This may best be answered by reviewing the evidence so far. Controlled clinical trials in pregnancy have shown that $\beta$ blocking drugs such as oxprenolol are equal, but not superior, to methyldopa. ${ }^{26} \mathrm{~A}$ postulated reduction in the side effects associated with methyldopa, such as drowsiness, was not proved. Follow up studies have shown no intellectual impairment in children up to the age of $7 \frac{1}{2}$ years born to mothers who were treated with methyldopa ${ }^{30}$ whereas corresponding studies after treatment with atenolol have only been performed in children up to the age of 1 year. ${ }^{24}$ Under these circumstances methyldopa must, at present, remain the antihypertensive drug of first choice when treatment is instigated primarily for the benefit of the fetus. Nevertheless, the short term safety of $\beta$ blockade has been proved, and as follow up studies proceed it is likely that $\beta$ blockers will come to be used at least as frequently as methyldopa.

M DE SWIET

Consultant Physician

Queen Charlotte's Maternity Hospital;

Senior Lecturer in Medicine,

University College London

Correspondence to: Cardiothoracic Institute, London SW3 6HP

1 Chamberlain GVP, Lewis PJ, de Swiet M, Bulpitt CJ. How obstetricians manage hypertension in pregnancy. Br Med J 1978;i:626-9.

2 Michael CA. Intravenous diazoxide in the treatment of severe pre-eclamptic toxaemia and eclampsia. Aust NZ J Obstet Gynaecol 1973;237:264-5.

3 Pennington JC, Picker RH. Diazoxide and the treatment of the acute hypertensive emergency in obstetrics. Med f Aust 1972;ii:1051-4.

4 Shoemaker CT, Meyers M. Sodium nitroprusside for control of severe hypertensive disease of pregnancy: a case report and discussion of potential toxicity. Am $\mathcal{J}$ Obstet Gynecol 1984;14S
. pregn $171-3$.
Michael CA. Use of labetalol in the treatment of severe hypertension during pregnancy. $\mathrm{Br} \mathcal{F} \mathrm{Clin}$ Pharmacol 1979;8:211.

6 Walters BNJ, Redman CWG. Treatment of severe pregnancy associated hypertension with the calcium antagonist nifedipine. Br $\mathcal{F}$ Obstet Gynaecol 1984;91:330-6.

Dudley DKL. Mini bolus diazoxide in the management of severe hypertension in pregnancy. $\mathrm{Am}$ f Obstet Gynecol 1985;151:196-200.

8 Ulmsten N, Andersson K-E, Wingerup L. Treatment of premature labor with the calcium antagonist nifedipine. Arch Gynecol 1980;229:1-5.

Collins R, Yusuf S, Peto R. Overview of randomised trial of diuretics in pregnancy. Br Med f 1985;290:17-23.

10 Sibai BM, Grossman RA, Grossman HG. Effect of diuretics on plasma volume in pregnancies with long term hypertension. Am $\mathcal{f}$ Obstet Gynecol 1984;150:831-5.

11 Northern Regional Health Authority Coordinating Group. Perinatal mortality: a continuing collaborative regional survey. BrMed F 1984;288:1717-20.

12 Leather HM, Humphreys DM, Baker P, Chadd MA. A controlled trial of hypotensive agents in hypertension in pregnancy. Lancet 1968;ii:488-90.

13 Redman CGW, Beilin LJ, Bonnar J, Ounsted MK. Fetal outcome in trial of antihypertensive treatment in pregnancy. Lancet 1976;ii:753-6.

14 Pruyn SC, Phelan JP, Buchanan GC. Long-term propranolol therapy in pregnancy: maternal and fetal outcome. Am J Obstet Gynecol 1979;135:485-9.

15 Habib A, McArthy JS. Effects on the neonate of propranolol administered during pregnancy. $\mathcal{f}$ Pediatr 1977;91:808-11.

16 Lieberman BA, Stirrat GM, Dohen SL, Beard RW, Pinker GD, Belsey E. The possible adverse effect of propranolol on the fetus in pregnancy complicated by severe hypertension. $\mathrm{Br} \mathcal{f}$ Obstet Gynaecol 1978;85:678-83.

17 Gallery EDM, Saunders DM, Hunyor SN, Gyory AL. Randomised comparison of methyldopa and oxprenolol for treatment of hypertension in pregnancy. BrMed f 1979;i: 1591-4.

18 Sandstrom B. Antihypertensive treatment with the adrenergic $\beta$ receptor blocker metoprolol during pr. Ancy Grocol Obstet Invest 1978:9:195-204.

19 Rubin PC, Butters L, Clark DM, et al. Placebo controlled trial of atenolol in treatment of Rubin PC, Butters L, Clark DM, et al. Placebo contro

20 Lardoux H, Gerard J, Blazquez G, Chouty F, Flouvat B. Hypertension in pregnancy: evaluation Lardoux H, Gerard J, Blazquez G, Chouty F, Flouvat B. Hypertension in preg
of two $\beta$ blockers atenolol and labetalol. Eur Heart $\mathcal{1}$ 1983;4(suppl G):35-40.

21 Melander A, Niklasson B, Inglemarsson I, Liedholm H, Schersten B, Stoberg NO. Transplacental passage of atenolol in man. Eur f Clin Pharmacol 1978;14:93-4.

22 Boutry MJH, Vert P, Bianchetti G, Dubrucq C, Morselli PL. Infants born to hypertensive mothers treated by acebutolol. Dev Pharmacol Ther 1982;4(suppl 1):109-15.

23 Fidler J, Smith V, de Swiet M. The excretion of oxprenolol and timolol in breast milk. Br $\mathcal{J}$ Obstet Gynaecol 1983;90:961-5.

24 Reynolds B, Butters L, Evans J, Adams T, Rubin PC. First year of life after the use of atenolol in pregnancy associated hypertension. Arch Dis Child 1984;59:161-3.

25 Rubin PC, Butters L, Clark D, et al. Obstetric aspects of the use in pregnancy associated hypertension of the $\beta$ adrenoceptor antagonist atenolol. Am $\mathcal{F}$ Obstet Gynecol 1984;150:389-92.

26 Fidler J, Smith V, Fayers P, de Swiet M. Randomised controlled comparative study of methyldopa and oxprenolol for the treatment of hypertension in pregnancy. $\mathrm{Br} \mathrm{Med} \mathfrak{J}$ 1983;286:1927-30.

27 Walker JJ, Belch JJF, Erwin L, et al. Labetalol and platelet function in pre-eclampsia. Lancet $1982 ;$ ii: 279 .

28 Lunnell NO, Nylund L, Lewander R, Sarby B. Acute effect of an antihypertensive drug, labetalol, on utero placental blood flow. Br f Obstet Gynaecol 1982;89:640-4

29 Rubin PC. Beta-blockers in pregnancy. N Engl f Med 1981;305:1323-6.

30 Cockburn J, Moar VA, Ounsted M, Redman CWG. Final report of study on hypertension during pregnancy: the effects of specific treatment on the growth and development of the children. Lancet 1982;i:647-9.

\section{Chasing the lead}

Lead has a strong claim to be the oldest of the agents toxic to man: there is scarcely a period of history in which there is not evidence for its harmful effects. It has also been more extensively studied than any other toxic material, and the industry of many hundreds of scientists delving away in their laboratories has produced such a welter of information as to be beyond the capacity of a single mind to retain. In the light of this truly prodigious knowledge why is not lead poisoning a disease of the past? One reason is that the metal may appear in the unsuspected places or where its presence has been forgotten.

In the eighteenth and nineteenth centuries it was axiomatic that lead workers would develop symptoms of poisoning because the conditions under which they worked were so badly controlled. In the Uncommercial Traveller Charles Dickens reports an old Irish lady who said to him of the women who worked in the white lead mills in the east end of London,". . . some of them gets lead-pisoned soon, and some of them gets lead-pisoned later, and some, but not many, niver. ..." There was also considerable danger from lead present in the environment-in water, food, and drink adulterated either accidentally or deliberately, cosmetics, tea, and even snuff. 
In our own day the large lead industries are much better controlled, and (in the developed countries at least) the emphasis is on the prevention of subclinical rather than clinical effects. The risk of excessive lead absorption is still high, however, in some occupations. Anyone who takes a high temperature flame to old painted metal may inhale a sufficiently great amount of lead fumes to poison himself, particularly if the work is carried out within a confined space. Such a man would not normally describe himself as a lead worker, so the physician needs to be especially careful when taking the occupational history in order to obtain precise details of the type of work undertaken.

Inhalation risks, however, are not the only ones to be considered in occupational lead poisoning. The risk from ingesting lead at work has frequently been played down, but in some circumstances it can be very important indeed. For example, Baxter and his colleagues found raised blood lead concentrations among a group of workers in a stained glass factory whose methods of work had scarcely changed since the middle ages ( $p$ 383). As the glass is fitted into the lead bars the hands inevitably become contaminated, and, unless great care is taken, some of this lead is transferred to the mouth. Where the risk to workers is from ingestion control strategies must be based on blood lead analyses; the concentrations of lead in the air are most unlikely to be raised and environmental measurements may thus induce an unwarranted sense of security.

So far as the general public is concerned the risk of contracting lead poisoning is almost entirely confined to ingestion. The ways in which our daily lead may be increased are many and various but new risks-or old risks in new disguises-continue to appear to perplex the physician.

A 19 year old girl who lived in an Arab village on the West Bank was admitted to hospital in Jerusalem with lead poisoning. ${ }^{1}$ The most striking clinical feature was her severe muscular weakness, particularly of the shoulder girdle, which improved only slowly after chelation treatment. The patient's mother was also found to have severe lead poisoning, and an investigation of some other members of the village found nine other persons, including a 2 week old baby who needed treatment in hospital and many others with raised blood lead concentrations who were treated at home. Subsequently, the search for patients with raised blood lead concentrations was widened and other affected villages were found. ${ }^{2}$ The cases of clinical poisoning clustered in household units but were unrelated to age or sex, and a common dietary item appeared to be the source of the lead. The water, olive oil, salt, sugar, and a wide variety of spices and condiments were analysed and found to be blameless. When locally ground flour from houses of affected families was analysed, however, it was found to contain lead in concentrations from 54 to 532 parts per million; the lead concentrations in locally ground flour from unaffected families was less than 10 parts per million.

The investigators next focused their attention on the flour mills. Freshly ground flour was found to be heavily contaminated although the grain was lead free. When caked flour was removed from grooves in the lower mill stone from one of the mills its lead content was found to be 940 parts per million; that in flour taken from grooves in the upper stone was 93 parts per million. When the stones were cleaned the lead content of the flour was considerably reduced.

The ultimate source of the lead was shown as soon as the driveshaft was examined. Both it and its housing were made of iron. As it had worn the housing had become loose; so to secure it again to the stone lead had been poured into the gap between the mill stone and the housing. The researchers then examined other West Bank mills and found that nearly a quarter produced flour with lead concentrations above 0.5 part per million, thus posing a risk to health on a large scale.

These important studies remind us that lead in the environment may be a serious threat to health if it finds its way into the diet-and that chasing the source may be slow and painstaking and require a great deal of detective work. Shades of the Devonshire colic!

H A WALDRON

Senior Lecturer in Occupational Medicine,

London School of Hygiene and Tropical Medicine,

London WC1E 7HT

1 Hershko C, Abrahamov A, Moreb J, et al. Lead poisoning in a West Bank Arab village. Arch Interm Med 1984;144: 1969-73.

2 Eisenberg A, Avni A, Grauer F, et al. Identification of community flour mills as source of lead poisoning in West Bank Arabs. Arch Intern Med (in press).

\section{Gastric microflora}

The advent of endoscopy and the use of antiulcer drugs have increased interest in normal gastric physiology and the microflora of the stomach. ${ }^{12}$ In health, fluid aspirated from the stomach has a $\mathrm{pH}$ of less than 2 and is usually sterile, except during meals, which introduce organisms from the mouth and food. The make up of this transient flora depends on the number of bacteria ingested, the food in which they are ingested, the gastric acidity, and the rate of gastric emptying - and the stomach's defence against bacterial invasion, consisting of organic acids, mucus, lysozyme, and immunoglobulins (mainly IgA). ${ }^{34}$

The bactericidal nature of gastric secretions is affected by alterations in $\mathrm{pH}$. In hypochlorhydria the number of bacteria found in the stomach increases and may include faecal type bacteria as well as oral flora. ${ }^{15}$ Such conditions occur in pernicious anaemia and after partial gastrectomy and vagotomy and pyloroplasty. Patients with hypochlorhydria are more susceptible to enteric infections such as cholera and salmonellosis since a lower infective dose will breach the weakened gastric bactericidal barrier. ${ }^{6}$

The gastric $\mathrm{pH}$ becomes less acid with age, increasing the quantity of bacteria, ${ }^{7}$ and a syndrome associated with bacterial overgrowth has been recognised as a cause of malabsorption. ${ }^{8} \mathrm{~A}$ similar picture has been described in association with the chronic diarrhoea of malnutrition in Third World countries. ${ }^{9}$

The type and numbers of organisms in the stomach are of importance in gastric surgery. Postoperative infections are much more frequent in patients with hypochlorhydria. Possibly a gastric aspirate could be Gram stained or cultured preoperatively to help in the choice of prophylaxis, ${ }^{10}$ but this is rarely practicable. A gastric aspirate with a $\mathrm{pH}$ of greater than 4 would suggest bacterial overgrowth and the need for prophylactic antibiotics. If the patient is taking an acid reducing drug this should be stopped 24 hours before surgery. " Patients in intensive care units develop Gram negative pneumonias more frequently, possibly owing to organisms from the stomach entering the respiratory tract, ${ }^{12}$ and the use of $\mathrm{H}_{2}$ blockers may have increased this problem.

Endoscopy has allowed more detailed investigation of the gastric microflora for the presence of bacteria, viruses, fungi, and parasites. The gastric parasites Anisakis ${ }^{13}$ and hookworm ${ }^{14}$ 